\title{
Effect of Planting Systems and Growing Media on Earliness, Yield and Quality of Strawberry Cultivation under Soilless Culture
}

\author{
Nafiye $\mathrm{ADAK}^{1 *}$, Hamide GUBBUK${ }^{2}$ \\ ${ }^{1}$ Akdeniz University, Technical Sciences Vocational School, Environmental Protection and Control Program, 07058, Antalya, \\ Turkey;nafiye@akdeniz.edu.tr (" correspondingauthor) \\ ${ }^{2}$ Akdeniz University, Faculty of Agriculture, Department of Horticulture, 07058, Antalya, Turkey; gubbuk@akdeniz.edu.tr
}

\begin{abstract}
Soilless growing is becoming an attractive option because of the contamination of agricultural land due to the use of excessive fertilisers and insecticides to get higher productivity per unit area and the yield advantage with soilless culture getting more yield per unit area than the conventional growing. Effects of two planting systems and various growing media on earliness, yield and quality (colour L, C, $\mathrm{h}^{\circ}$, the rupture of calyx, firmness, total soluble solid, acidity and vitamin $\mathrm{C}$ ) in strawberry (Fragaria $\times$ ananassa Duch.) cultivation under soilless culture was studied. Two different planting seasons i.e., summer and fall were chosen and growing media was composed of peat $(\mathrm{Pt})$, perlite $(\mathrm{Pr})$, cocopeat $(\mathrm{Co})$, volcanic tuff $(\mathrm{Vlc})$ and their combinations. Results showed that fall planting system was favourable in terms of earliness but summer planting gave better results in terms of total yield. Moreover, the first harvest of summer planting was February, whereas the first harvest of the fall planting was in December. Early yield in the fall planting comprised $36.0 \%$ of the total yield. The Co and the Co+Vlc media were more favourable than other media with regard to yield, earliness and fruit quality. In addition vegetation period was found from January to May and it was observed that as the total soluble solids values increased in fruits, acidity and vitamin $\mathrm{C}$ values decreased.
\end{abstract}

Keywords: Fragaria $\times$ ananassa Duch., 'Camarosa' cultivar, substrate, quality

\section{Introduction}

Turkey is among the leading countries cultivating strawberry, after the USA and Mexico, with an annual production of 353173 tonnes (FAO, 2012). In Turkey, strawberry cultivation is carried out under a wide range of ecological conditions, such as protected cultivation in coastal strips using short-day cultivars, or open-field cultivation in upland with neutral cultivars. Applications to increase the earliness and yield have been tested and applied, especially in the Mediterranean coastline (Adak et al., 2003). In Turkey, the seedling types used include bare root, plug and frigo (cold stored) and the planting systems used are summer and early fall planting. In soil cultivation, plant spacing is adjusted according to the seedling type and the soil structure on a rate of approximately 50 000-70 000 plant ha ${ }^{-1}$.

Soilless culture methods, used mostly for products such as tomatoes and peppers, have also been initiated be used for strawberry plants as well. The number of plants per unit area has increased especially via soilless culture applications; thus, the yield per unit area has also increased (ParaskevopoulouParoussis et al., 1995; Ozeker et al., 1999; Paranjpe et al., 2003a; Paranjpe et al., 2008). Fruit quality has also increased due to the fact that this type of cultivation allows for controlled cultivation. Substrate selection is important for soilless cultivation system planning along with the cultivation system (Favaro and Marano, 2003). In this regard, Paranjpe $e t$ al. (2003b) stated that pine shaving is heavily used in Florida besides substrates such as perlite and peat. Linardakis and Manios (1991) have stated that the highest yield with vertical systems is attained from perlite $(80 \%)+$ peat $(20 \%)$; and Lopez-Medina et al. (2004) from coconut coir. Lieten (2004) suggested that rockwool has adverse effects on the vegetative development of strawberries and their root developments, whereas coconut coir is well suited for use with strawberries. In Turkey and the rest of the world, consumption of peat resources, decrease in perlite reserves, and waste problem of rockwool etc. have directed people towards the use of renewable materials that can be easily obtained by local resources at cheap prices. Hence, alternative substrates should be tried and compared to peat, perlite and rockwool, which are used widely both in the world and in Turkey (Barkham, 1993; Robertson, 1993; Frolking et al., 2001; García Gómez et al., 2002).

The objective of this study was to examine the soilless strawberry cultivation possibilities in Turkey and under Mediterranean ecological conditions and to determine the 
effects of the most suited planting systems and growing media on earliness, yield and quality.

\section{Materials and methods}

This study was conducted under greenhouse conditions of the private sector research area $\left(36^{\circ} 50^{\prime} 37^{\prime \prime} \mathrm{N}\right.$; $\left.30^{\circ} 50^{\prime} 31^{\prime \prime} \mathrm{E}\right)$ which is a high, unheated and modern greenhouse ( $10 \mathrm{~m}$ width x 40 m length x $6.5 \mathrm{~m}$ height) in 2012-2013. 'Camarosa' (Fragaria $\times$ ananassa Duch.) strawberry cultivar, respectively summer and fall planting systems were used. Frigo seedlings were used for summer planting and the planting was carried out on June $15^{\text {th }}, 2012$. In contrast, plug type seedlings were used for the fall planting and the planting was carried out on September $15^{\text {th }}$, 2012. The following growing media were used:

1. Coconut coir (100\%) (Co); 2. Peat (100\%) (Pt); 3. Coconut coir+Volcanic tuff $(50 \%+50 \%)$ (Co+Vlc); 4. Peat+Volcanic tuff $(50 \%+50 \%)(\mathrm{Pt}+\mathrm{Vlc}) ; 5$. Peat + Perlite $(50 \%$ $+50 \%)(\mathrm{Pt}+\mathrm{Pr})$.

The physical properties of the growing media are as follows: weight per unit volume was $0.18 \mathrm{~g} \mathrm{~cm}^{-3}$ for peat, $0.13 \mathrm{~g} \mathrm{~cm}^{-3}$ for coconut coir, and $0.66 \mathrm{~g} \mathrm{~cm}^{-3}$ for volcanic tuff; the total porosity was $93 \%$ for peat, $66 \%$ for perlite, $91 \%$ for coconut coir, and $71 \%$ for volcanic tuff; the air capacity was $33 \%$ for peat, $53 \%$ for perlite, $35 \%$ for coconut coir, and $55 \%$ for volcanic tuff; the water holding capacity was $65 \%$ for peat, $38 \%$ for perlite; $62 \%$ for coconut coir, and $35 \%$ for volcanic tuff.

This experiment was laid out under greenhouse conditions and the highest number of seedlings per unit area was used as much as possible. Punched pots having $75 \mathrm{~cm}$ in length, $25 \mathrm{~cm}$ in width and $25 \mathrm{~cm}$ in depth and white in colour were used and were placed on benches designed with a width of $25 \mathrm{~cm}$, length of $13.5 \mathrm{~m}$ and height of $75 \mathrm{~cm}$ which was placed to have $1 \%$ slope to ensure free drainage. Among the benches, $75 \mathrm{~cm}$ distances were left in order to perform the cultural practices. This trial was carried out at two different times with plug and frigo seedlings, with 10 seedlings planted in each pot $\left(13.33\right.$ seedling $\left.\mathrm{m}^{-2}\right)$.

Dosatron injection system equipped with time adjustment irrigation and fertilisation properties was used and the plant nutrient solution was prepared in accordance with Lieten (2004). $\mathrm{pH}$ of the solution was set to 6.0 throughout the cultivation season and the Electrical Conductivity (EC) values were between $1.5-1.8 \mathrm{mS} \mathrm{cm}$ depending on the plant growing cycle (Lieten, 2008; Cantliffe et al., 2008).

Drainage channels were placed underneath the pots during the experiment and optimum irrigation was attained by measuring the drainage amount obtained from this channel in one day. Accordingly, fertigation was calculated depending on drainage amounts which were $30 \%$ for summer months and 20\% for winter months (Cantliffe et al., 2008; Montesano et al., 2010; Gul et al., 2011). Fertigations of $266.66 \mathrm{ml} / \mathrm{plant} /$ day (10 irrigations per day) from the end of July to the end of September, 213.28 $\mathrm{ml} /$ plant/day (8 irrigations per day) from the end of September to the beginning of March and $239.94 \mathrm{ml} / \mathrm{plant} /$ day (9 irrigations per day) from the beginning of March to the end of May were carried out.

In order to ensure pollination, bumble bees were placed starting from the beginning of November and these hives were replaced every 6 weeks. Chemical control methods were sprayed against diseases and pests such as red spiders, aphids, leaf worms and powdery mildew disease throughout the production period.
During the 2012-2013 season, crown diameter measurements via digital calliper (at the widest section of the crown) and leaf number measurements were carried out on plants in December and in February. Leaf nutrient concentrations were evaluated on 15 young leaves (the 15 most recently matured leaves) which were selected randomly from each parcel during March. Nitrogen content of the leaves was determined using the modified Kjeldahl method; phophorous content using the vanado molibdo phosphoric yellow method, whereas the potassium, calcium, magnesium concentrations were measured by using Atomic Absorption Spectrophotometry (Kacar, 1972). First harvesting dates along with early and total yield values were determined. Early yield was determined in December and in January, whereas total yield was in December and in June. Yield values were calculated by dividing the total weight of harvested fruits from one parcel during the vegetation period by the number of plants. Colour, calyx removal, fruit firmness, total soluble solid (TSS), titrable acid and vitamin $C$ values were also determined. These fruit analyses were carried out on 15 (fifteen) randomly selected fruits from each parcel in each harvest. Fruit skin colours were measured via brand chromometer in terms of "L", "a" and "b" values, which were expressed in terms of $\mathrm{C}$ (chroma) and $\mathrm{h}^{\circ}$ (hue). $\mathrm{C}$ and $\mathrm{h}^{\circ}$ values were determined according to the formulae given below:

$$
C: \sqrt{ }\left(a^{2}+b^{2} ; \quad h^{\circ}: \tan ^{-1}(b / a) .\right.
$$

The $h^{\circ}$ value expresses the redness and yellowness of the colour mathematically: as the hue value decreases the colour approaches red and as it increases the colour moves away from red. In contrast, the chroma value mathematically represents the brightness and opacity of the colour and higher chroma values indicate that the colour is brighter. Calyx removal and firmness in fruits was determined via digital penetrometer. TSS content of the fruit sap was measured using a hand refractometer and titratable acidity was determined by titrating the samples obtained from the fruit sap with $\mathrm{NaOH}(0.1 \mathrm{~N})$ until they reached $\mathrm{pH}$ 8.2. Citric acid content was then determined as given below:

$\%$ Acid $=$ Citric acid constant $(0.007) \times U$ sed $\mathrm{NaOH} \times \mathrm{NaOH}$ factorx 100.

Vitamin C (L-Ascorbic Acid) amount was calculated via spectrophotometric method and was expressed as mg ascorbic acid $100 \mathrm{ml}^{-1}$ fresh fruit according to Pearson and Churchill (1970).

Studies were planned according to the experimental design named randomised parcels in factorial order with four replicates of 20 plants per replicate. LSD test was used to compare the means. Statistical analyses were performed using SAS and MSTAT softwares.

\section{Results}

\section{Crown diameter, leaf number}

Effect of planting systems on crown diameter was determined to be statistically significant, whereas its effect on leaf number was not significant (Table 1). Effect of the growing media on crown diameter and leaf number was statistically significant. Highest crown diameter and leaf number values were observed in the Co and the Co+Vlc media. The PS x GM interaction was not found to be statistically significant (Table 1).

\section{Leaf nutrient concentrations}

Effects of planting systems and growing media on leaf N, P, 
206

$\mathrm{K}, \mathrm{Ca}$ and $\mathrm{Mg}$ concentrations were statistically insignificant (Table 2). Even though nutrient concentration changed based on the planting systems and growing media, following ranges were measured during march measurements for $\mathrm{N} 2.78 \%$ and 2.85\%; $\mathrm{P} 0.63 \%$ and $0.68 \% ; \mathrm{K} 3.00 \%$ and $3.22 \%$; Ca between $1.65 \%$ and $1.68 \%$; and $\mathrm{Mg} 0.48 \%$ and $0.50 \%$. Regarding interaction between PS $\times$ GM, insignificant relationships were fixed.

Table 1.Effect of various planting systems and growing media on crown diameter and leafnumber in strawberry

\begin{tabular}{|c|c|c|}
\hline Factors & Crown diameter $(\mathrm{mm})$ & Leaves plant $^{-1}$ (no) \\
\hline Summer & $37.72 \mathrm{~b}^{*}$ & 22.73 \\
\hline Fall & $40.20 \mathrm{a}$ & 21.33 \\
\hline LSD $\% 5$ & 2.120 & NS \\
\hline Co & $43.49 \mathrm{a}$ & $23.25 \mathrm{a}$ \\
\hline Pt & $36.67 \mathrm{~b}$ & $21.17 \mathrm{ab}$ \\
\hline $\mathrm{Co}+\mathrm{Vlc}$ & $44.07 \mathrm{a}$ & $23.42 \mathrm{a}$ \\
\hline $\mathrm{Pt}+\mathrm{Vlc}$ & $36.05 \mathrm{~b}$ & $20.67 \mathrm{~b}$ \\
\hline $\mathrm{Pt}+\mathrm{Pr}$ & $34.54 \mathrm{~b}$ & $21.67 \mathrm{ab}$ \\
\hline LSD $\% 5$ & 4.738 & 2.461 \\
\hline ** PS x GM & NS & NS \\
\hline
\end{tabular}

**PS (Planting systems) x GM (Growing media)

*Values in the same column that are followed by different letters are significantly different using LSD comparison test.

Table 2. Effect of various planting systems and growing media on the N, P, K, Ca and Mg content in strawberry leaves

\begin{tabular}{lccccc}
\hline Factors & $\mathrm{N}(\%)$ & $\mathrm{P}(\%)$ & $\mathrm{K}(\%)$ & $\mathrm{Ca}(\%)$ & $\mathrm{Mg}(\%)$ \\
\hline Summer & 2.85 & 0.64 & 3.11 & 1.68 & 0.49 \\
Fall & 2.81 & 0.65 & 3.10 & 1.67 & 0.49 \\
LSD \%5 & $\mathrm{NS}$ & $\mathrm{NS}$ & $\mathrm{NS}$ & $\mathrm{NS}$ & $\mathrm{NS}$ \\
$\mathrm{Co}$ & 2.85 & 0.68 & 3.14 & 1.67 & 0.49 \\
$\mathrm{Pt}$ & 2.83 & 0.65 & 3.22 & 1.67 & 0.50 \\
$\mathrm{Co}+\mathrm{Vlc}$ & 2.82 & 0.63 & 3.00 & 1.65 & 0.48 \\
$\mathrm{Pt}+\mathrm{Vlc}$ & 2.87 & 0.63 & 3.08 & 1.68 & 0.50 \\
$\mathrm{Pt}+\mathrm{Pr}$ & 2.78 & 0.64 & 3.07 & 1.68 & 0.48 \\
LSD $\% 5$ & $\mathrm{NS}$ & $\mathrm{NS}$ & $\mathrm{NS}$ & $\mathrm{NS}$ & $\mathrm{NS}$ \\
$\mathrm{PS} \times \mathrm{GM}$ & $\mathrm{NS}$ & $\mathrm{NS}$ & $\mathrm{NS}$ & $\mathrm{NS}$ & $\mathrm{NS}$ \\
\hline
\end{tabular}

\section{Earliness and total yield}

For the "frigo" (cold stored) seedlings planted on $17^{\text {th }}$ July, 2012 during the 2012-2013 growing period, first flowering came out on $10^{\text {th }}$ January, 2013; whereas the first harvesting was done on $3^{\text {tr }}$ of February, 2013 (summer plantation). For the plug seedlings planted on $15^{\text {th }}$ September, 2012, first flowering took place on $30^{\text {th }}$ October, 2012 whereas first harvesting occurred on $7^{\text {th }}$ December, 2012 (fall plantation) (Table 3).

Earliness was not determined for the summer plantings with frigo seedlings (Table 4) whereas an early yield of $264.67 \mathrm{~g} \mathrm{plant}^{-1}$ was obtained during the fall plantings with plug seedlings (from December to the end of February). Summer planting was determined to be more advantageous in comparison to fall planting in terms of total yield. In fact, a total yield of $998.67 \mathrm{~g}$ plant ${ }^{-1}$ was obtained during the summer planting and a total yield of 725.33 g plant $^{-1}$ was obtained for the fall planting.

Whereas the effects of growing media on early yield were not determined to be statistically significant, their effects on total yield were determined to be statistically significant. Highest total yield values were determined in the Co+Vlc and the Co media, while the lowest yields were determined in the Pt media (Table 4).

\section{Fruit skin color $\left(L, C, h^{\circ}\right)$}

Effects of planting systems and growing media on fruit skin colour $\mathrm{L}, \mathrm{C}, \mathrm{h}^{\mathrm{o}}$ were not determined to be statistically significant (Table 5). Even though it differs according to the planting systems and growing media, value of $L$ varied between 29.20 and 31.64; value of $C$ varied between 37.72 and 39.62; and the value of $^{\circ}$ varied between 24.65 and 28.20 .

\section{Calyx removal fruit firmness}

Effects of planting systems on calyx removal and fruit firmness were statistically insignificant (Table 6). Even though no statistically significant effect of growing media on calyx removal was determined, the growing media had an important effect on fruit firmness Highest value of fruit firmness was 0.80 $\mathrm{kg} \mathrm{cm}^{-2}$ in the Co+Vlc medium. The interaction between PS $\mathrm{x}$ GM were also not statistically significant.

\section{Total soluble solid, Titrable acid and Vitamin C content}

Effects of planting systems on TSS, titratable acid and Vitamin C were not determined to be statistically significant (Table 7). In contrast, the effect of growing media on TSS was not statistically significant and the highest TSS amount was detected in mixture media, such as the $\mathrm{Co}+\mathrm{Vlc}, \mathrm{Pt}+\mathrm{Vlc}$ and the $\mathrm{Pt}+\mathrm{Pr}$. In terms of acid and Vitamin C, no difference was determined among the applications and the acid amount varied between $1.10 \%$ and $1.12 \%$; whereas the Vitamin C amount varied among $55.35 \%$ and $57.21 \%$.

Table 3. First flowering and first harvesting dates of strawberry for planting systems in the 2012-2013 growing period

\begin{tabular}{lccc}
\hline $\begin{array}{l}\text { Planting } \\
\text { System }\end{array}$ & $\begin{array}{c}\text { Planting } \\
\text { Date }\end{array}$ & $\begin{array}{c}\text { First Flowering } \\
\text { Date }\end{array}$ & $\begin{array}{c}\text { First Harvesting } \\
\text { Date }\end{array}$ \\
\hline Summer & 17.07 .2012 & 10.01 .2013 & 3.02 .2013 \\
Fall & 15.09 .2012 & 30.10 .2012 & 7.12 .2012 \\
\hline
\end{tabular}

Table 4. Effect of various planting systems and growing media on early and total yield of strawberry

\begin{tabular}{lcc}
\hline Factors & Early yield $\left(\mathrm{g} \mathrm{plant}^{-1}\right)$ & Total yield $\left(\mathrm{g} \mathrm{plant}^{-1}\right)$ \\
\hline Summer & - & $998.67 \mathrm{a}$ \\
Fall & 264.67 & $725.33 \mathrm{~b}$ \\
LSD $\% 5$ & & 30.88 \\
Co & 276.67 & $865.00 \mathrm{ab}$ \\
$\mathrm{Pt}$ & 263.33 & $836.67 \mathrm{~b}$ \\
$\mathrm{Co}+\mathrm{Vlc}$ & 283.33 & $903.33 \mathrm{a}$ \\
$\mathrm{Pt}+\mathrm{Vlc}$ & 240.00 & $860.00 \mathrm{ab}$ \\
$\mathrm{Pt}+\mathrm{Pr}$ & 260.00 & $845.00 \mathrm{~b}$ \\
$\mathrm{LSD} \% 5$ & $\mathrm{NS}$ & 48.824 \\
$\mathrm{PS} \times \mathrm{GM}$ & $\mathrm{NS}$ & $\mathrm{NS}$ \\
\hline
\end{tabular}

Table 5. Effect of planting systems and growing media on fruit skin colour $\left(\mathrm{L}, \mathrm{C}, \mathrm{h}^{\circ}\right)$ of strawberry fruits

\begin{tabular}{lccc}
\hline \multirow{2}{*}{ Factors } & \multicolumn{3}{c}{ Fruit Skin Colour } \\
\cline { 2 - 4 } & $\mathrm{L}$ & $\mathrm{C}$ & $\mathrm{h}^{\circ}$ \\
\hline Summer & 29.60 & 39.16 & 26.15 \\
Fall & 31.64 & 38.25 & 26.57 \\
\hline LSD $\% 5$ & $\mathrm{NS}$ & $\mathrm{NS}$ & $\mathrm{NS}$ \\
$\mathrm{Co}$ & 31.45 & 38.87 & 24.65 \\
$\mathrm{Pt}$ & 30.93 & 39.62 & 28.19 \\
$\mathrm{Co}+\mathrm{Vlc}$ & 30.74 & 39.55 & 24.82 \\
$\mathrm{Pt}+\mathrm{Vlc}$ & 30.79 & 37.76 & 26.04 \\
$\mathrm{Pt}+\mathrm{Pr}$ & 29.20 & 37.72 & 28.20 \\
\hline LSD $\% 5$ & $\mathrm{NS}$ & $\mathrm{NS}$ & $\mathrm{NS}$ \\
PS $x$ GM & $\mathrm{NS}$ & $\mathrm{NS}$ & $\mathrm{NS}$ \\
\hline
\end{tabular}


Table 6. Effect of planting systems and growing media on the calyx removal of strawberry fruit and fruit firmness

\begin{tabular}{lcc}
\hline \multicolumn{1}{c}{ Factors } & Calyx Removal $(\mathrm{kg})$ & Fruit Firmness $\left(\mathrm{kg} \mathrm{cm}^{-2}\right)$ \\
\hline Summer & 0.87 & 0.70 \\
Fall & 0.85 & 0.75 \\
LSD $\% 5$ & $\mathrm{NS}$ & $\mathrm{NS}$ \\
$\mathrm{Co}$ & 0.87 & $0.78 \mathrm{ab}$ \\
$\mathrm{Pt}$ & 0.85 & $0.73 \mathrm{ab}$ \\
$\mathrm{Co}+\mathrm{Vlc}$ & 0.87 & $0.80 \mathrm{a}$ \\
$\mathrm{Pt}+\mathrm{Vlc}$ & 0.86 & $0.70 \mathrm{ab}$ \\
$\mathrm{Pt}+\mathrm{Pr}$ & 0.85 & $0.67 \mathrm{~b}$ \\
LSD $\% 5$ & $\mathrm{NS}$ & 0.11 \\
PS $\mathrm{GM}$ & $\mathrm{NS}$ & $\mathrm{NS}$ \\
\hline
\end{tabular}

Table 7. Effect of various planting systems and growing media on TSS, acidity and Vitamin Cin strawberry fruits

\begin{tabular}{lccc}
\hline Factors & TSS $(\%)$ & Acid $(\%)$ & Vitamin C (\%) \\
\hline Summer & 7.57 & 1.10 & 55.68 \\
Fall & 7.60 & 1.12 & 56.64 \\
LSD \%5 & NS & NS & NS \\
Co & $7.51 \mathrm{~b}$ & 1.11 & 56.80 \\
Pt & $7.48 \mathrm{~b}$ & 1.12 & 57.21 \\
Co+Vlc & $7.69 \mathrm{a}$ & 1.12 & 55.72 \\
Pt+Vlc & $7.62 \mathrm{a}$ & 1.10 & 55.35 \\
Pt+Pr & $7.65 \mathrm{a}$ & 1.11 & 55.71 \\
LSD \%5 & 0.0958 & $\mathrm{NS}$ & $\mathrm{NS}$ \\
PS x GM & $\mathrm{NS}$ & $\mathrm{NS}$ & $\mathrm{NS}$ \\
\hline
\end{tabular}

Table 8. Monthly variation in TSS, Acidity and Vitamin C content of strawberry fruits during the 2012-2013 production season

\begin{tabular}{lccc}
\hline Factors & TSS (\%) & Acid (\%) & Vitamin C (\%) \\
\hline January & $6.33 \mathrm{e}$ & $1.28 \mathrm{a}$ & $65.55 \mathrm{a}$ \\
February & $7.13 \mathrm{~d}$ & $1.22 \mathrm{~b}$ & $63.56 \mathrm{a}$ \\
March & $7.28 \mathrm{c}$ & $1.09 \mathrm{c}$ & $57.43 \mathrm{~b}$ \\
April & $8.14 \mathrm{~b}$ & $1.04 \mathrm{~d}$ & $51.16 \mathrm{c}$ \\
May & $9.06 \mathrm{a}$ & $0.92 \mathrm{e}$ & $43.10 \mathrm{~d}$ \\
LSD $\% 5$ & 0.0958 & 0.0371 & 2.7474 \\
\hline
\end{tabular}

Effects of months on the TSS, acid and Vitamin C values of fruits during the 2012-2013 experimental period are shown in Table 8. As can be seen in this table, the effects of time on TSS, acid and Vitamin $\mathrm{C}$ were found be statistically significant. As a matter of fact, the TSS value increases as acidity and Vitamin C values decrease between January and May. The TSS value varied between 6.33\% and 9.06\%; the acidity values varied among $1.28 \%$ and $0.92 \%$; and the Vitamin C values among $65.55 \%$ and $43.10 \%$.

\section{Discussion}

Our results showed that earliness, yield and quality changed according to planting system. Different results have been also obtained in the previous studies. Tropea (1980) stated that the total yield obtained from frigo seedlings was higher but later in comparison to those of plug seedlings, whereas Pipattanawong et al. (1995) stated that the vegetative development was very strong for frigo seedlings. Similar results have been obtained in the current study as well. In the current study, the early yield for fall planting of plug seedlings was determined to be higher and the total yield was determined to be lower than those of frigo seedlings. The first harvesting dates varied from researcher to researcher. Takeda (1999a) reported the first harvest date for soilless strawberry culture systems in November-December; Adak et al. (2003) reported the first flowerings for conventional fall planting in the beginning of November and the first harvest in the middle of December; Paranjpe et al. (2003c) stated that the first harvesting was made at the end of November for the protected hanging system; and Vasilakakis et al. (1999) reported that the first harvesting was made at the end of Decemberbeginning of January for the cultivation system in perlite medium with plug seedlings.

Yield per plant values also differed for studies carried out in various media by different researchers. Linardakis and Manios (1991) stated that the highest yield was obtained in peat + perlite medium with $250 \mathrm{~g} \mathrm{plant}^{-1}$. Takeda (1999a) stated that the highest yield via nutrient film technique method for the 'Camarosa' type reached to $1.2 \mathrm{~kg}$ plant ${ }^{-1}$; Takeda (1999b) reported a yield of $700 \mathrm{~g} \mathrm{plant}^{-1}$ in the planting of the 'Chandler' type with plug seedlings. Takeda and Hokanson (2003) stated that the variation was between $0.6 \mathrm{~kg}_{\text {plant }}{ }^{-1}$ and $1.2 \mathrm{~kg}$ plant $\mathrm{t}^{-1}$ even though the yield per plant values changed according to the type of plant in the soilless culture studies that they carried out using frigo transplants; Cantliffe et al. (2008) stated that they acquired a yield per plant value of $250 \mathrm{~g}$ for plug transplants grown in coconut coir and pine shaving medium; and Hotchmunt et al. (2008) stated that the highest yield of $725 \mathrm{~g}$ plant $^{-1}$ was obtained from the 'Camarosa' type and in peat+perlite medium and that the early yield varied between 93 and 107 g plant $^{-1}$ as a result of the studies carried out using plug seedlings. However, studies regarding coconut coir applications are very limited and the few studies that have been carried out were determined to be advantageous in terms of yield (LopezMedina et al., 2004; Lieten, 2008). Navarro et al. (2010) stated that total fruit yield per plant decreased significantly with increasing salinity in perlite. Carmona et al. (2012) stated that the grapevine marc and grapevine stalk substrates had no limiting characteristics for its use as a medium for the cultivation of ornamental plants in container, and could replace conventional substrates, such as peat and coconut fiber.

Research carried out for the pomological analyses on fruits obtained via soilless culture have also differed among researchers. Vasilakakis et al. (1999) have stated that cultivation varies between $4.5 \%$ and $9.5 \%$ and titrable acid content varies between $0.8 \%$ and $1.8 \%$ for strawberry fruits in column culture. Tagliavini et al. (2005) stated that the TSS content varies between $6.2 \%$ and $4.7 \%$, and the titrable acid content varies between 10.3 and $7.3 \mathrm{meq} / \mathrm{l}$ malic acid/100 g and Eltez and Tüzel (2007) reported that the TSS content varies between $7.625 \%$ and $5.825 \%$, whereas the $\mathrm{pH}$ value varies between 4 and 3.98 and the vitamin $\mathrm{C}$ amount varies between 21.370 and $27.870 \mathrm{mg} / 100 \mathrm{ml}$. In addition, Paranjpe $e$ t al. (2004) stated that as the temperature increases the quality of fruit decreases (firmness, TSS, acidity) throughout the growing season and Cantliffe et al. (2008) stated that TSS amount did not vary from medium to medium.

In this study, earliest harvest was obtained in the fall planting of plug transplants in the beginning of December. No difference was determined between media in terms of yield and quality. The Co and the Co+Vlc media were determined to be more advantageous than the other media in terms of total yield per plant and all of the fruit quality criteria analysed. Thus, these results were found to be mostly in agreement with the aforementioned results. 


\section{Conclusions}

In this study, which examines soilless strawberry cultivation possibilities in Turkey in Mediterranean ecological conditions via protected soilless culture, various effects of planting systems and growing media on earliness and yield have been found. The first harvest was obtained in the beginning of February for the summer planting of frigo transplants, whereas for the all planting of plug transplants, the first harvest was obtained in the beginning of December. Hence, the early yield determined in December and January was only obtained for the fall plantings. Summer planting of frigo transplants seems to be more advantageous in terms of total yield. A yield increase of almost $27 \%$ was obtained for the summer planting in comparison with that of the fall planting. In terms of growing media, the $\mathrm{Co}$ and the $\mathrm{Co}+\mathrm{Vlc}$ media have been determined to be more advantageous in terms of yield, earliness and all of the other examined criteria. Also, subject to the advancement of vegetation (from January to May), acidity and vitamin $\mathrm{C}$ values decreased as the TSS value increased.

\section{Acknowledgements}

This paper was supported by the Scientific Research Projects Administration Unit of Akdeniz University. The authors thanks to Dr. Tomas Ayala-Silva, Agricultural Research Service, United States Department of Horticulture (USDA-ARS, Florida/U.S.); Dr. Anil Khar, ARS Senior Scientist, Maharashtya, India; Emeritus Prof. Richard A. Weismiller, University of Maryland, U.S.A, for their critical review of this manuscript.

\section{References}

Adak N, Gübbük H, Pekmezci M (2003). The growing possibilities of some strawberry cultivars grown under protected cultivation in Antalya conditions (in Turkish). Türkiye IV. Ulusal Bahçe Bitkileri Kongresi Antalya 313-315.

Barkham JP (1993). For peat's sake: conservation or exploitation? Biodiv Conserv 2:556-566.

Cantliffe DJ, Castellanos JZ, Paranjpe AV (2008). Yield and quality of greenhouse grown strawberries as affected by nitrogen level in coco coir and pine bark media. Proc Fla State Hort Soc 120:157-161.

Carmona E, Moreno MT, Aviles M, Ordovas J (2012). Composting of wine industry wastes and their use as a substrate for growing soilless ornamental plants. Spanish Journal of Agricultural Research 10(2):482-491.

Eltez RZ, Tüzel Y (2007). The effects of different soilless culture techniques in "A-shape" system on the yield and quality of greenhouse strawberry production (in Turkish). Ege Üniversitesi Ziraat Fakültesi Dergisi 44(1):15-27.

FAO (2012). Statistical database. http://faostat.fao.org/site/339/default.aspx (accessed in August 9, 2014).

Favaro JC, Marano RP (2003). Alterations in the physical and physico-chemical properties of a substrate based on composted sawdust and perlite with polycyclic tomato crops. Spanish Journal of Agricultural Research 1(3):105-109.
Frolking S, Roulet NT, Moore TR, Richard PJH, Lavoie M, Muller SD (2001). Modeling northern peatland decomposition and peat accumulation. Ecosystems 4:479-498.

Garcia Gomez A, Bernal MP, Roig A (2002). Growth of ornamental plants in two composts prepared from agroindustrial wastes. Bioresource Technology 83(2):81-87.

Gul A, Tuzel Y, Tuzel H, Irget M, Kidoglu F, Tepecik M (2011). Effects of nutrition and irrigation on sweet pepper production in volcanic tuff. Spanish Journal of Agricultural Research 9(1):221229.

Kacar BN (1972). Plant Analysis (in Turkish). Ankara Üniversitesi Ziraat Fakültesi Yayınları Ankara 453:644-645.

Lieten F (2004). Substrates as an alternative to methyl bromide for strawberry fruit production in Northern Europe in both protected and field production. Proceedings of International Conference on Alternatives to Methyl Bromide 41-46.

Linardakis DK, Manios BI (1991). Hydroponic culture of strawberries in plastic greenhouse in a vertical system. Acta Hort 287:317-326.

Lopez Medina J, Peralbo A, Flores F (2004). Closed soilless growing system: a sustainable solution for strawberry crop in Huelva (Spain). Acta Hort 213-215.

Montesano F, Parente A, Santamaria P (2010). Closed cycle subirrigation with low concentration nutrient solution can be used for soilless tomato production in saline conditions. Scientia Horticulturae 124(3):338-344.

Navarro JM, Garrido C, Flores P, Martinez V (2010). The effect of salinity on yield and fruit quality of pepper grown in perlite. Spanish Journal of Agricultural Research 8(1):142-150.

Ozeker E, Eltez RZ, Tuzel Y, Gul A, Onal K, Tanrisever A (1999). Investigations on the effect of different growing media on the yield and quality of strawberries grown in vertical bags. Acta Hort 491:409-412.

Paranjpe AV, Cantliffe DJ, Lamb EM, Stoffella PJ, Powell CA (2003a). Winter strawberry production in greenhouses using soilless substrates: an alternative to methyl bromide soil fumigation. Proc Fla State Hort Soc 116:98-105.

Paranjpe AV, Cantliffe DJ, Rondon S, Chandler CK, Brecht JK, Brecht EJ, Cordasco K (2003b). Trends in fruit yield and quality, susceptibility to powdery mildew (Sphaerotheca macularis), and aphid (Aphis gossypii) infestation for seven strawberry cultivars grown without pesticides in a passively ventilated greenhouse using pinebark as soilless substrate. Proc Fla State Hort Soc 116:63-72.

Paranjpe AV, Cantliffe DJ, Lamb EM, Stoffella PJ, Powell CA (2003c). Increasing winter strawberry production in north-central Florida using passive ventilated greenhouses and high plant densities. Acta Hort 626:269-276.

Paranjpe A, Cantliffe DJ, Lamb EM, Stoffella PJ (2004). Economic feasibility of production strawberries in a passively ventilated greenhouse in North-Central Florida. Proc Fla State Hort Soc 117:27-37.

Paranjpe AV, Cantliffe DJ, Stoffella PJ, Lamb EM, Powell CA (2008). Relation of plant density to fruit yield of 'Sweet Charlie' strawberry grown in a pine bark soilless medium in a high-roof passively ventilated greenhouse. Scientia Horticulturae 115:117-123. 
Paraskevopoulou-Paroussi G, Grafiadellis M, Paroussis E (1995). Takeda F (1999a). Strawberry production in soilless culture systems. Precocity, plant productivity and fruit quality of strawberry plants grown in soil and soilless culture. Acta Hort 408:109-118.

Pearson D, Churchill AA (1970). The chemical analyses of foods. Gloucester Place 104:233.

Pipattanawong N, Fujishige N, Yamane K, Ogata R (1995). Growth and development of four day-neutral strawberries under hydroponic system with or without chilling. Journal of the Japanese Society for Horticultural Science 64(1):95-102.

Robertson RA (1993). Peat, horticulture and environment. Biodiv Conserv 2(5):541-547.

Tagliavini M, Baldi E, Lucchi P, Antonelli M, Sorrenti G, Baruzzi G, Faedi W (2005). Dynamics of nutrients uptake by strawberry plants (Fragaria $x$ ananassa Dutch.) grown in soil and soilless culture. EuropJ Agronomy 23(1):15-25.

\section{Acta Hort 481:289-295.}

Takeda F (1999b). Out-of-season greenhouse strawberry production in soilless substrate. Adv Strawberry Res 18:4-15.

Takeda F, Hokanson SC (2003). Strawberry fruit and plug plant production in the greenhouse. Acta Hort 626:283-285.

Tropea M (1980). The control of strawberry plant nutrition in the sack culture. Proceedings Fifth International Congress on Soilless Culture 477-484.

Vasilakakis M, Alexandridis A, El Fadl S, Anagnostou K (1999). Effect of substrate (new or used perlite), plant orientation on the coloumn and irrigation frequency on yield efficiency of strawberry plants (cv. Selva) and fruit quality. Cahiers Options Mediterraneennes 31:357363. 